\title{
Annealing effects on the optical and electrochemical properties of tantalum pentoxide films
}

\author{
Wei REN ${ }^{a, *}$, Guang-Dao YANG ${ }^{b}$, Ai-Ling $\mathrm{FENG}^{c}$, Rui-Xia MIAO ${ }^{a}$, \\ Jun-Bo XIA ${ }^{a}$, Yong-Gang $\mathrm{WANG}^{b}$ \\ ${ }^{a}$ School of Science \& School of Electronic Engineering, Xi' an University of Posts \& \\ Telecommunications, Xi'an 710121, China \\ ${ }^{b}$ School of Physics and Information Technology, Shaanxi Normal University, Xi'an 710119, China \\ ${ }^{c}$ Institute of Physics \& Optoelectronics Technology, Baoji University of Arts and Sciences, Baoji 721016, China
}

Received: September 27, 2020; Revised: January 25, 2021; Accepted: February 8, 2021

(c) The Author(s) 2021.

\begin{abstract}
Tantalum pentoxide $\left(\mathrm{Ta}_{2} \mathrm{O}_{5}\right)$ has attracted intensive attention due to their excellent physicochemical properties. $\mathrm{Ta}_{2} \mathrm{O}_{5}$ films were synthesized via electron beam evaporation (EBE) and subsequently annealed at different temperatures ranging from 300 to $900{ }^{\circ} \mathrm{C}$. X-ray diffraction (XRD) results show that amorphous $\mathrm{Ta}_{2} \mathrm{O}_{5}$ thin films form from 300 to $700{ }^{\circ} \mathrm{C}$ and then a phase transition to polycrystalline $\beta-\mathrm{Ta}_{2} \mathrm{O}_{5}$ films occurs since $900{ }^{\circ} \mathrm{C}$. The surface morphology of the $\mathrm{Ta}_{2} \mathrm{O}_{5}$ films is uniform and smooth. The resulted $\mathrm{Ta}_{2} \mathrm{O}_{5}$ films exhibit excellent transmittance properties for wavelengths ranging from 300 to $1100 \mathrm{~nm}$. The bandgap of the $\mathrm{Ta}_{2} \mathrm{O}_{5}$ films is broadened from 4.32 to $4.46 \mathrm{eV}$ by annealing. The $900{ }^{\circ} \mathrm{C}$ polycrystalline film electrode has improved electrochemical stability, compared to the other amorphous counterparts.
\end{abstract}

Keywords: $\mathrm{Ta}_{2} \mathrm{O}_{5}$ films; anneal; optical property; electrochemical stability

\section{Introduction}

$\mathrm{Ta}_{2} \mathrm{O}_{5}$ (tantalum pentoxide), which forms at either tetragonal $\left(\alpha-\mathrm{Ta}_{2} \mathrm{O}_{5}\right)$ or orthogonal $\left(\beta-\mathrm{Ta}_{2} \mathrm{O}_{5}\right)$ crystalline phase, is one of the important transition-metal oxides with high refractive index $(n=2.02-2.16)$, high dielectric constant $(\varepsilon=20-46)$, wide bandgap $(4.0-4.5 \mathrm{eV})$, and wide transmission spectrum [1]. $\mathrm{Ta}_{2} \mathrm{O}_{5}$ thin films have been widely used in new types of optoelectronic devices, electroluminescent devices [2,3], optical waveguides [4], optical coatings [5,6], and optical filters [7], owing its excellent thermal and chemical

* Corresponding author.

E-mail: renwei@xupt.edu.cn stability, high mechanical strength, and good resistance to friction. For examples, a protective layer of $\mathrm{Ta}_{2} \mathrm{O}_{5}$ is often coated on thermal sensors utilizing its higher heat resistance and mechanical strength in satellites. $\mathrm{Ta}_{2} \mathrm{O}_{5}$ and its ternary alloys have been widely used as passivation layer in MOS-based devices [8]. Electrode materials in modern batteries often need a $\mathrm{Ta}_{2} \mathrm{O}_{5}$ cover layer to obtain long-term electrochemical energy storage and charge-and-discharge cycle toughness [9]. The crystalline structure obtained by annealing and the reduction of oxygen vacancies can increase the laser damage threshold. Thin-film saturable absorber materials typically need a coating of $\mathrm{Ta}_{2} \mathrm{O}_{5}$ on its top surface to maintain a high laser damage threshold and sustain higher output-power in ultrafast lasers [10,11]. Because 
of its compatibility with commercial integrated circuit technology, $\mathrm{Ta}_{2} \mathrm{O}_{5}$ is a promising non-silicon dielectric material for microelectronic devices and the ideal capacitive material for next generation dynamic random-access memory [12] and multi-chip modules $[13,14]$. With its high acidity, $\mathrm{Ta}_{2} \mathrm{O}_{5}$ can serve as a catalyst for important processes such as the oxidation of alkanes and the pollution reduction [15]. In addition, $\mathrm{Ta}_{2} \mathrm{O}_{5}$ is an important dielectric material for thin-film capacitors, and has been successfully used for anode oxidization of electrodes in lithium batteries [16].

The fabrication of $\mathrm{Ta}_{2} \mathrm{O}_{5}$ films using various methods has been investigated intensively and the potential application in industry has been developed during the past two decades. Hudner et al. [17] reported the growth of $\beta$-phase $\mathrm{Ta}_{2} \mathrm{O}_{5}$ films on $\mathrm{Si}(100)$ via electron beam evaporation in an atomic oxygen plasma at a substrate temperature of $650{ }^{\circ} \mathrm{C}$. Mannequin et al. [18] discussed the difference in the structural and chemical properties of amorphous $\mathrm{Ta}_{2} \mathrm{O}_{5}$ thin films grown via EBE and RF sputtering. Using chemical vapor deposition (CVD), Devine et al. [19] developed a new plasma-enhanced process to obtain high-quality amorphous $\mathrm{Ta}_{2} \mathrm{O}_{5}$ thin films, which were used as gate insulators to make p-channel MOS transistors. Using atomic layer deposition (ALD) method, Chaneliere et al. [3] and Lukosius et al. [20] characterized the structural and electrical properties of $\mathrm{Ta}_{2} \mathrm{O}_{5}$ films and explored the possibility of applying $\mathrm{Ta}_{2} \mathrm{O}_{5}$ thin films in microelectronic devices. Pulsed laser deposition (PLD) was used by Krishnan et al. [21] to obtain crystalline $\mathrm{SnO}_{2}$-doped $\mathrm{Ta}_{2} \mathrm{O}_{5}$ thin films with good optical properties at relatively low temperatures. Byeon et al. [22] and Reddy et al. [23] used magnetron sputtering method to synthesize $\mathrm{Ta}_{2} \mathrm{O}_{5}$ films and investigated the possibility of $\mathrm{Ta}_{2} \mathrm{O}_{5}$ films as dielectric materials in capacitors of integrated circuits. Xia et al. [16] chose anodizing method to fabricate a self-supporting porous $\mathrm{Ta}_{2} \mathrm{O}_{5}$ film for a battery electrode material with a large number of charge and discharge cycles. $\mathrm{Ta}_{2} \mathrm{O}_{5}$ films were also produced via the sol-gel method [24] and polycrystalline $\mathrm{Ta}_{2} \mathrm{O}_{5}$ film formed after heat treatment above $400{ }^{\circ} \mathrm{C}$, which decreased optical absorption. The performance adjustment of $\mathrm{Ta}_{2} \mathrm{O}_{5}$ films was made at the same time. $\mathrm{Xu}$ et al. [10] improved the oxygen vacancy problem of evaporated $\mathrm{Ta}_{2} \mathrm{O}_{5}$ film via annealing, and increased the bandgap and the laser damage resistance threshold of the film. Zhang et al. [25] used spectroscopic ellipsometry (SE) to characterize the refractive index of evaporated $\mathrm{Ta}_{2} \mathrm{O}_{5}$ films with different thicknesses and studied the optical properties of ultrathin film as a function of thickness. Masse et al. [26] studied $\mathrm{Ta}_{2} \mathrm{O}_{5}$ thin films at different annealing temperatures ranging from room temperature up to $900{ }^{\circ} \mathrm{C}$ and found mutual diffusion of oxygen, silicon, and Ta at high temperatures. He et al. [27] studied the effects of oxygen pressure on film roughness and optical transmission of PLD-grown $\mathrm{Ta}_{2} \mathrm{O}_{5}$ films.

Technically, the synthesis of $\mathrm{Ta}_{2} \mathrm{O}_{5}$ film is feasible using any of the above methods. Annealing of the deposited $\mathrm{Ta}_{2} \mathrm{O}_{5}$ films is necessary to improve film crystallinity as well as the refractive index, absorption coefficient, and the electrical properties of the films [26,28-32]. In this work, EBE, a simple film-growth method, had been employed to deposit amorphous $\mathrm{Ta}_{2} \mathrm{O}_{5}$ films on quartz and $\mathrm{Si}$ substrates to produce optical coatings with uniform, smooth surfaces and a high film density [33-35]. However, when evaporated $\mathrm{Ta}_{2} \mathrm{O}_{5}$ films undergo high temperature annealing, the effects on the film's structural, morphological, optical, and electrochemical properties are still not clear. Therefore, our purpose is to investigate the properties of $\mathrm{Ta}_{2} \mathrm{O}_{5}$ samples at different annealing temperatures, and the research work should bear the significance to improve the long-term stability of the photocatalyst/ electrocatalyst electrodes.

\section{Experimental}

$\mathrm{Ta}_{2} \mathrm{O}_{5}$ films were synthesized with the following procedure. The source materials were small $\mathrm{Ta}_{2} \mathrm{O}_{5}$ pieces (purity 99.99\%), which were put into a pure copper crucible in a commercial high-vacuum EBE system (ZZS700, Xing Nan Technology Co., China). The experimental device is shown in Fig. 1. Opticallypolished $\mathrm{Si}(100)$ substrates with $4 \mathrm{k} \Omega \cdot \mathrm{cm}^{2}$ and the thickness of $650 \mu \mathrm{m}$ (for the structural and morphological characterization) and quartz with the thickness of $500 \mu \mathrm{m}$ (for transmittance studies) were cut into pieces $(10 \mathrm{~mm} \times 10 \mathrm{~mm})$ and cleaned (ultrasonic cleaning in acetone, alcohol, and DI water, respectively, for $15 \mathrm{~min}$ ). They were placed on a rotating workpiece which was heated with a contact heater in the upper vacuum chamber to maintain a constant substrate temperature of $300{ }^{\circ} \mathrm{C}$. The substrate temperature was monitored by a thermocouple with an accuracy of $\pm 1{ }^{\circ} \mathrm{C}$ in real time. The evaporation source-to-substrate distance 


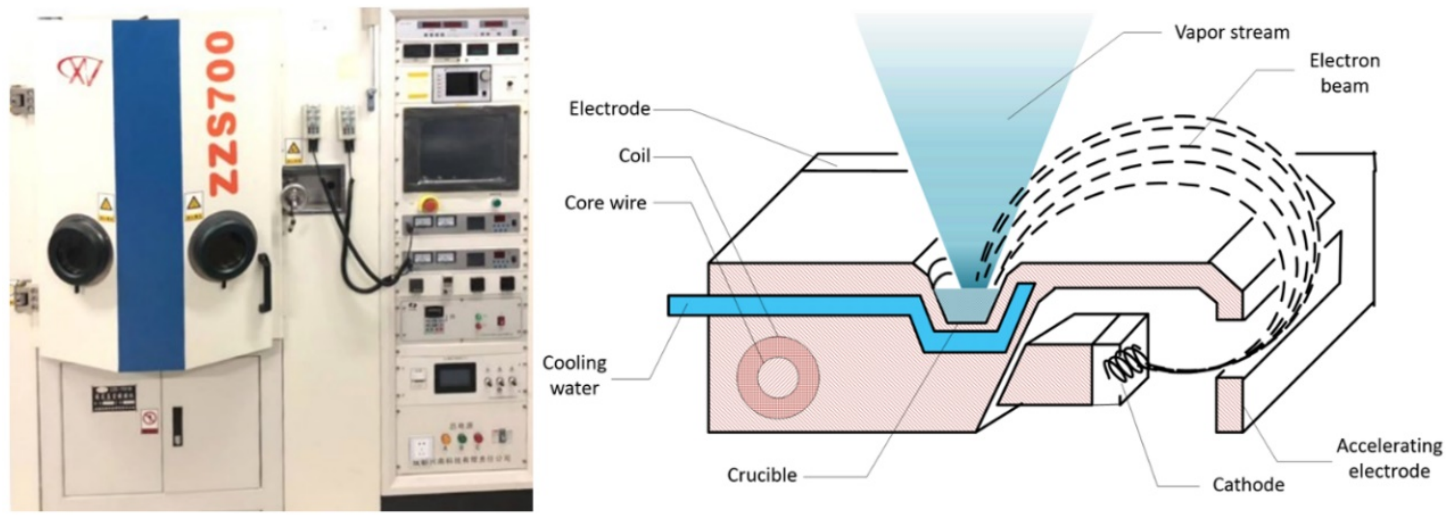

Fig. 1 Physical object and schematic diagram of the experimental device.

was $\sim 130 \mathrm{~cm}$, and the evaporation source-to-electrongun-filament distance was $\sim 25 \mathrm{~mm}$. Before the evaporation, the substrate surface was cleaned for $120 \mathrm{~s}$ using an ion source. The vacuum system consists of a low-vacuum mechanical pump and a high-vacuum molecular pump. The pump and vacuum monitor can (in real time) display the vacuum level in the system pipeline and the evaporation chamber. When the evaporation chamber was pumped down below $6 \times 10^{-4}$ $\mathrm{Pa}$, the materials started to be evaporated.

A quartz crystal monitor (Inficon G10) was used to display the real-time film deposition rate. The target thickness value of the $\mathrm{Ta}_{2} \mathrm{O}_{5}$ film was pre-set to $50 \mathrm{~nm}$ twice in control panel of the EBE system $(100 \mathrm{~nm}$ thick in total). The filament current of the electron gun was $310 \mathrm{~mA}$. The film growth rate was set to be very slow $(0.2-0.4 \mathrm{~nm} / \mathrm{s})$ so as to allow sufficient duration for film growth with uniform grain distribution. After the film growth was done and the chamber naturally cooled down, the samples were taken out of the chamber and subsequently annealed at 300, 500, 700, and $900{ }^{\circ} \mathrm{C}$ for $30 \mathrm{~min}$ in a tube furnace (with the temperature rising at $5{ }^{\circ} \mathrm{C} / \mathrm{min}$ ). After film deposition, the samples in the tube furnace are naturally cooling down in air to the room temperature with the cooling rate estimated to be about $2{ }^{\circ} \mathrm{C} / \mathrm{min}$.

The surface morphology of the samples was characterized using atomic force microscopy (AFM, Dimension ICON) and field-emission scanning electron microscopy (FE-SEM, Nova Nanosem 450). Phase identification was performed via XRD with the $\mathrm{Cu} \mathrm{K} \alpha$ radiation line ( $\lambda=1.5418 \AA$, Shimadzu $7000 \mathrm{SAS})$. The optical transmittance spectra of the $\mathrm{Ta}_{2} \mathrm{O}_{5}$ films with different annealing temperatures were measured via a UV-visible spectrophotometer (UV3300) for a wavelength range of 200-1100 $\mathrm{nm}$. Using an electrochemical workstation (CHI760E), the capacitive test was performed on the sample by cyclic voltammetry. The electrochemical test uses a three- electrode system for a scan rate range of $0.1-0.5 \mathrm{~V} / \mathrm{s}$, using a thin film sample as the working electrode, metal platinum as the counter electrode, and calomel electrode (SCE) as the reference electrode. The electrolyte uses $1 \mathrm{M} \mathrm{NaCl}$ electrolyte. The surface valence state is characterized by X-ray photoelectron spectroscopy (XPS, Kratos Analytical Ltd.), the binding energy was calibrated using C 1s $(284.8 \mathrm{eV})$ spectrum of hydrocarbon that always remained in the XPS analysis chamber.

\section{Results and discussion}

Figure 2 shows the XRD diffraction patterns of the prepared $\mathrm{Ta}_{2} \mathrm{O}_{5}$ thin films on Si substrates at different annealing temperatures. When comparing these four curves $\left(300-900{ }^{\circ} \mathrm{C}\right)$ with the Standard PDF Card \#25-0922 [16,18,36], only $900{ }^{\circ} \mathrm{C}$ curve exhibits (001),

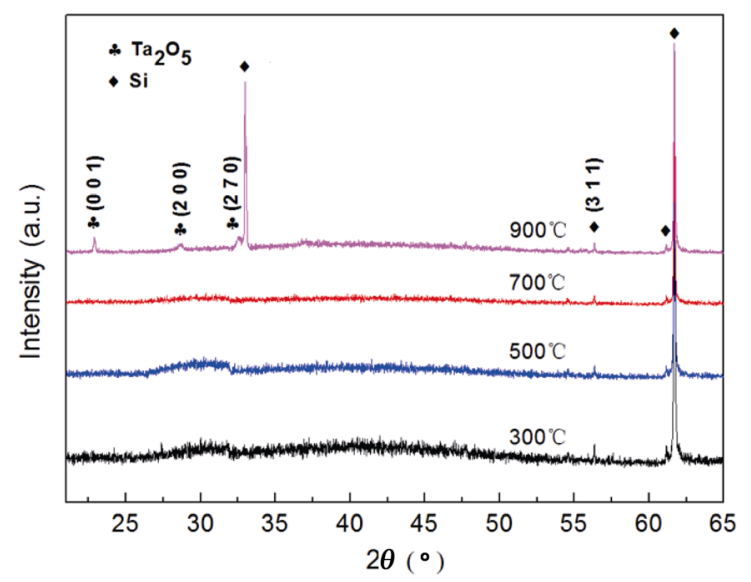

Fig. 2 XRD patterns of the $\mathrm{Ta}_{2} \mathrm{O}_{5} / \mathrm{Si}(100)$ samples annealed at $300-900{ }^{\circ} \mathrm{C}$. 
(200), and (270) orientation peaks of orthorhombicphase $\mathrm{Ta}_{2} \mathrm{O}_{5}\left(\beta-\mathrm{Ta}_{2} \mathrm{O}_{5}\right)$ film. The other three curves do not exhibit $\mathrm{Ta}_{2} \mathrm{O}_{5}$ peak except for a broad hump at $27^{\circ}-32^{\circ}$. The presence of this hump infers that the $\mathrm{Ta}_{2} \mathrm{O}_{5}$ films are amorphous in the temperature range of 300-700 ${ }^{\circ} \mathrm{C}$. A polycrystalline $\mathrm{Ta}_{2} \mathrm{O}_{5}$ film forms until $900{ }^{\circ} \mathrm{C}$. Considering that polycrystalline $\mathrm{Ta}_{2} \mathrm{O}_{5}$ films have been reported by annealing at $800{ }^{\circ} \mathrm{C}$ [36], the crystallization of $\mathrm{Ta}_{2} \mathrm{O}_{5}$ films may start at less than $800{ }^{\circ} \mathrm{C}$. All the above results are consistent with previous reports [17,18,33,36,37].

Figure 3 illustrates AFM images of the planar morphology of $\mathrm{Ta}_{2} \mathrm{O}_{5} / \mathrm{Si}(100)$ sample at $300-900{ }^{\circ} \mathrm{C}$ anneal. The $R a$ (the maximum roughness) values of these samples at $300,500,700$, and $900{ }^{\circ} \mathrm{C}$ are 0.402 , $0.865,0.780$, and $2.263 \mathrm{~nm}$, respectively; and the $R q$ (the root mean square roughness) values of these samples at $300-900{ }^{\circ} \mathrm{C}$ are $0.520,1.151,0.989$, and $3.132 \mathrm{~nm}$, respectively. The overall color of the diagram for the $300-900{ }^{\circ} \mathrm{C}$ is dark brown, which indicates that the film surface is quite uniform and very dense [38]. Specifically, the light brown and white dots, representing the raised structures, are relatively small. The height errors are even within the scale of a single molecular layer, indicating the film surface has atomic flatness [39].

Figure 4 shows planar and cross-sectional SEM images and EDS mapping of $\mathrm{Ta}_{2} \mathrm{O}_{5}$ thin films at different annealing temperatures. Table 1 shows the atomic weight percentage of oxygen and tantalum in EDS mapping energy spectra. In Fig. 4(a), it exhibits that the particle size of $\mathrm{Ta}_{2} \mathrm{O}_{5}$ films decreases greatly with increasing of the temperatures (from 300 to
$700{ }^{\circ} \mathrm{C}$ ). Significant changes occurred at $900{ }^{\circ} \mathrm{C}$, where the film surface morphology becomes texturized structure in spite of the film surface keeping flat. This phenomenon is consistent with XRD results of the $\mathrm{Ta}_{2} \mathrm{O}_{5}$ film transition from amorphous phase to crystalline phase at high temperature. Figure 4(b) measures the sample thickness values of 157.5, 105.7, 113.5 , and $116.0 \mathrm{~nm}$ for $300-900{ }^{\circ} \mathrm{C}$ films. According to Ref. [25], the film thickness below $40 \mathrm{~nm}$ could affect the optical properties of $\mathrm{Ta}_{2} \mathrm{O}_{5}$ thin film dramatically. When the film thickness exceeds $40 \mathrm{~nm}$, the refractive index of the film will be close to the value of bulk $\mathrm{Ta}_{2} \mathrm{O}_{5}$. Thus, the optical properties of the obtained films are thickness-independent. In Fig. 4(c) and Table 1, it shows the elemental distributions of Ta and $\mathrm{O}$ on the film surface of four films, confirming high elemental distribution uniformity of all film surfaces.

Since the optical properties of $\mathrm{Ta}_{2} \mathrm{O}_{5}$ films can reflect the variation in the crystalline quality and energy bandgap of the films, the transmittance spectra of four films on the quartz substrate are plotted in the wavelength range of $200-1100 \mathrm{~nm}$ in Fig. 5. All the $\mathrm{Ta}_{2} \mathrm{O}_{5}$ films exhibit relatively good optical transmittance over the wavelength range of $310-1100 \mathrm{~nm}$. For $300{ }^{\circ} \mathrm{C}$ curve, the transmittance rate of the film is around 0.6 to $0.77(60 \%$ to $77 \%)$ in the wavelength range of 310-660 nm. For 500 and $700{ }^{\circ} \mathrm{C}$ curves, the transmittance rates of the two samples increase to $0.75-0.82(75 \%-82 \%)$ in the wavelength range of 310-660 nm. This phenomenon occurs probably because the optical properties of the samples were
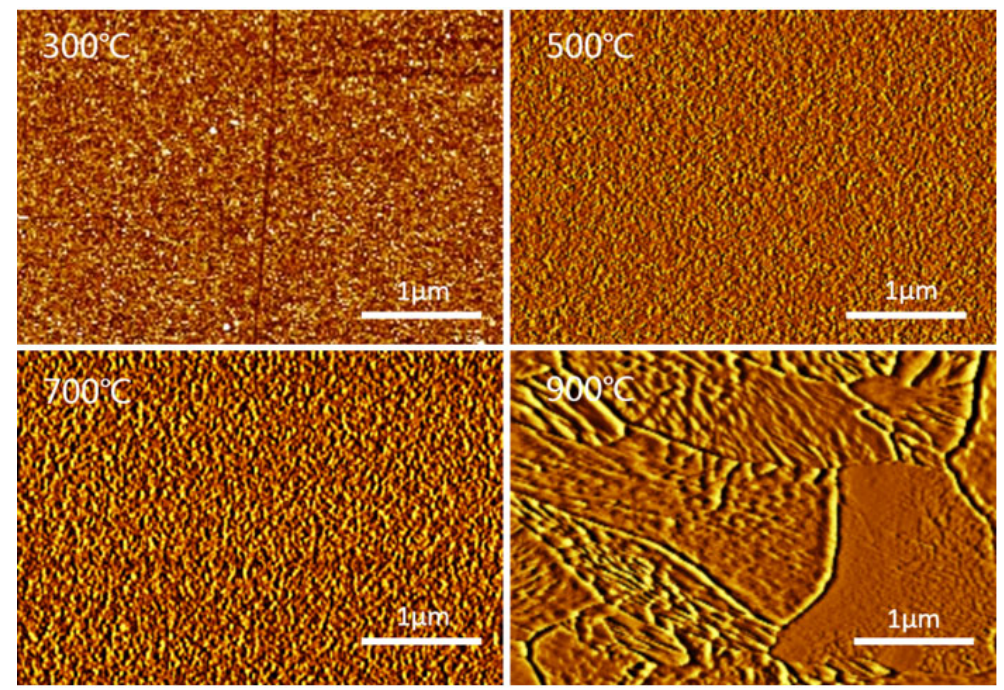

Fig. 3 AFM images of the planar morphology of the $\mathrm{Ta}_{2} \mathrm{O}_{5} / \mathrm{Si}(100)$ samples at $300-900{ }^{\circ} \mathrm{C}$ anneal. 


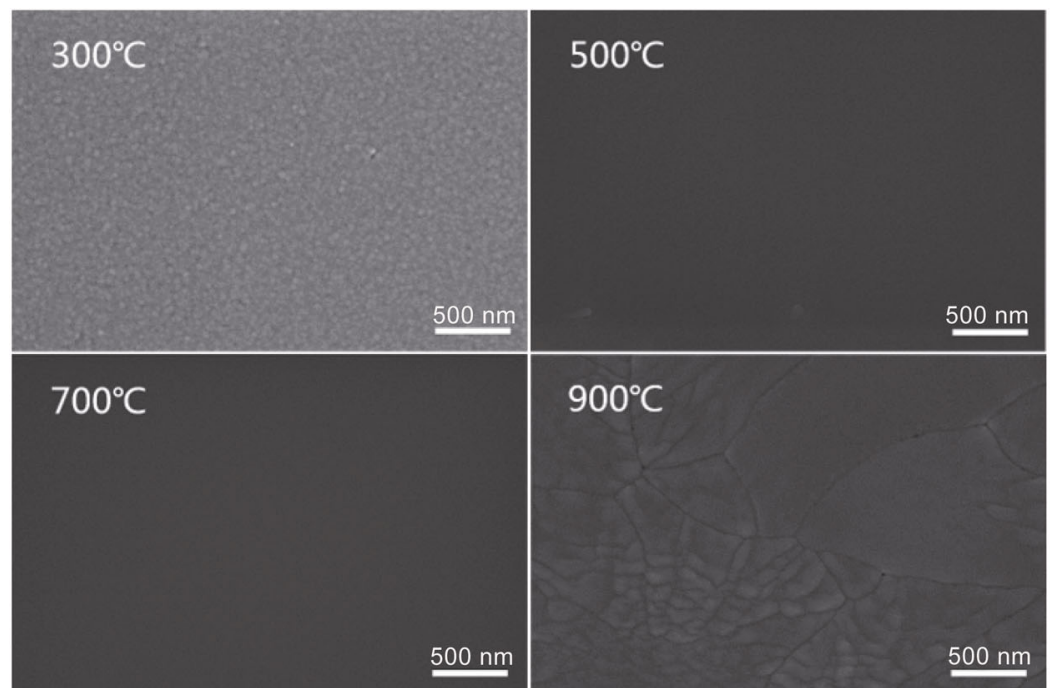

(a)

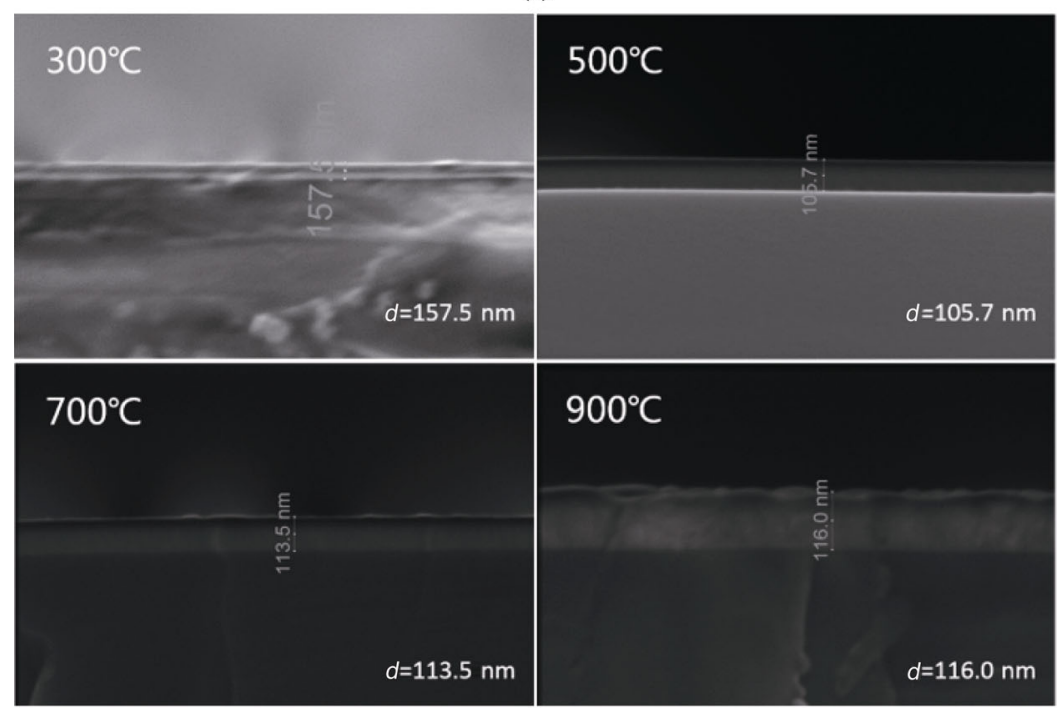

(b)

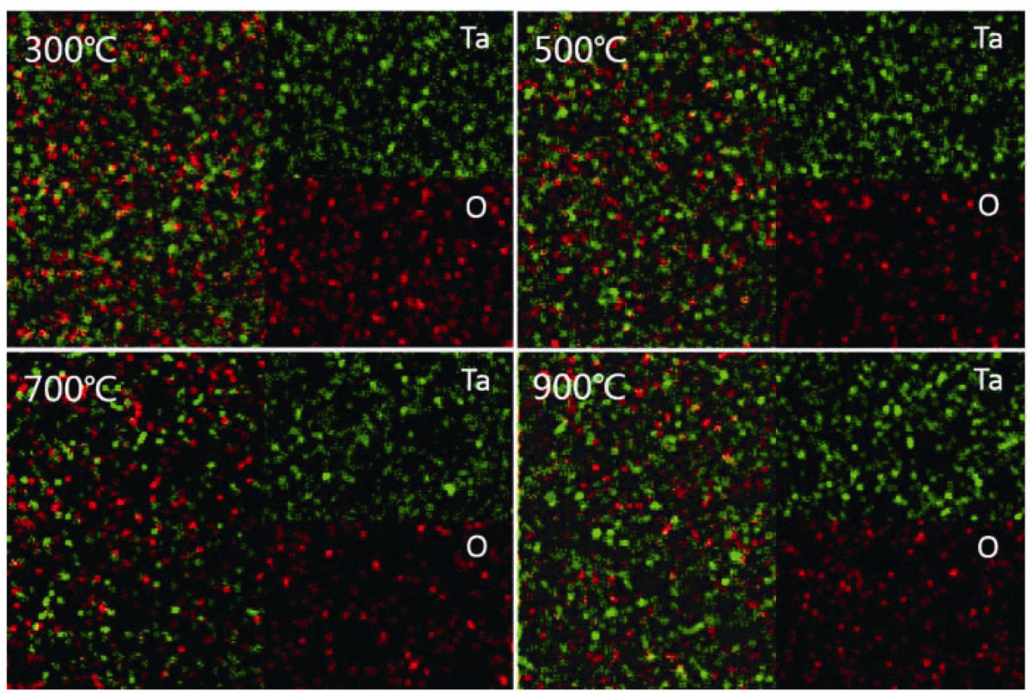

(c)

Fig. 4 (a) Planar and (b) cross-sectional SEM images; (c) EDS mapping energy spectra of $\mathrm{Ta}_{2} \mathrm{O}_{5}$ thin films annealed at different temperatures. 
Table 1 Atomic weight percentage of $O$ and Ta in EDS mapping energy spectra

\begin{tabular}{rrrrr}
\hline & $300{ }^{\circ} \mathrm{C}$ & $500{ }^{\circ} \mathrm{C}$ & $700{ }^{\circ} \mathrm{C}$ & $900{ }^{\circ} \mathrm{C}$ \\
\hline $\mathrm{Ta}(\%)$ & 92.318 & 90.914 & 92.885 & 91.870 \\
$\mathrm{O}(\%)$ & 7.682 & 9.086 & 7.115 & 8.130 \\
\hline
\end{tabular}

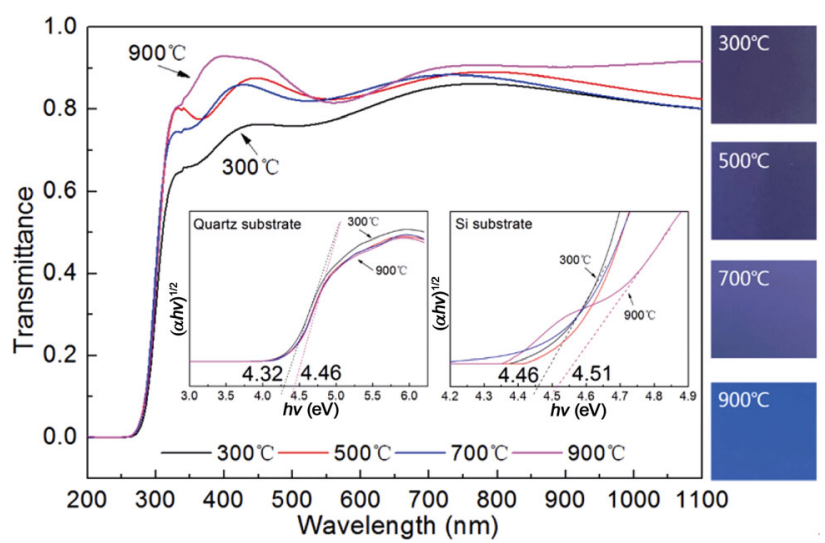

Fig. 5 Transmittance spectra of the $\mathrm{Ta}_{2} \mathrm{O}_{5} /$ quartz samples within the incidence light wavelength of $200-1100 \mathrm{~nm}$, and sample color contrast illustration. The inset: $(\alpha h v)^{1 / 2}$ versus incidence photon energy of $\mathrm{Ta}_{2} \mathrm{O}_{5}$ films.

relatively not so good with low density and there are many defects in the $\mathrm{Ta}_{2} \mathrm{O}_{5}$ film at low temperature anneal $[10,36]$. Another reason may be that $300{ }^{\circ} \mathrm{C}$ film is thicker $(157.5 \mathrm{~nm})$ than the other three films (around $110 \mathrm{~nm}$ ). Unlike Ref. [26], the transmittance spectra of 500 and $700{ }^{\circ} \mathrm{C}$ are very similar probably because the hexagonal structured $\mathrm{Ta}_{2} \mathrm{O}_{5}\left(\delta-\mathrm{Ta}_{2} \mathrm{O}_{5}\right)$ forms at $700{ }^{\circ} \mathrm{C}$ in Ref. [26] while the film crystallization of 500 and $700{ }^{\circ} \mathrm{C}$ does not occur yet. In addition, the optical transmittance continues to substantially increase in the wavelength ranges of $300-550 \mathrm{~nm}$ and $700-1100 \mathrm{~nm}$, from 700 to $900{ }^{\circ} \mathrm{C}$ since crystalline $\mathrm{Ta}_{2} \mathrm{O}_{5}$ phase starts to form at $900{ }^{\circ} \mathrm{C}$ and thus there are fewer defects in $900{ }^{\circ} \mathrm{C}$ film. Finally, contrary to the results in Ref. [36], where the transmittance of the prepared films decreased when the annealing temperatures increased from 600 to $1000{ }^{\circ} \mathrm{C}$, the transmittance in Fig. 5 generally increases with temperature. The film morphology of $\mathrm{Ta}_{2} \mathrm{O}_{5}$ may explain the difference: the surface roughness values of those films at 600,800 , and $1000{ }^{\circ} \mathrm{C}$ in Ref. [36] were $9.364,31.367$, and $43.699 \mathrm{~nm}$, respectively, which are much rougher than those of $300-900{ }^{\circ} \mathrm{C}$. It is clear that the rougher the film surface is, the stronger the light scattering in the film, or the smaller the film transmittance.

Moreover, the transmittance drops rapidly to zero from 310 to $273 \mathrm{~nm}$, which is due to strong light-absorption in this region. The minimum absorption is below $273 \mathrm{~nm}$. If the energy that corresponds to the $273 \mathrm{~nm}$ absorption edge is defined as the bandgap of the film, then, according to the formula:

$$
E=h c / \lambda
$$

The bandgap of the samples is $\sim 4.54 \mathrm{eV}$, which is close to the $4.2 \mathrm{eV}$ of bulk $\mathrm{Ta}_{2} \mathrm{O}_{5}$ [21]. In addition, the $\mathrm{Ta}_{2} \mathrm{O}_{5}$ film coverage reduces the substrate transmittance slightly and the film color of $300-900{ }^{\circ} \mathrm{C}$ turns to light blue from dark blue in Fig. 5. As the temperature increases, the optical transmittance of the $\mathrm{Ta}_{2} \mathrm{O}_{5}$ film generally increases. The transmittance of $900{ }^{\circ} \mathrm{C}$ film remains above $90 \%$ from 374 to $1100 \mathrm{~nm}$ (slightly below $90 \%$ at $500-600 \mathrm{~nm}$ ), and reaches a maximum of $93 \%$ at $400 \mathrm{~nm}$. Thus, annealing facilitates removal of the voids and holes of thin films and the consequent improvement of the film optical quality as well as the film color.

Further, Fig. 5 shows the bandgap $\left(E_{\mathrm{g}}\right)$ variation of the $\mathrm{Ta}_{2} \mathrm{O}_{5}$ films with annealing temperatures. The film $E_{\mathrm{g}}$ value can be derived using Tauc [40] formula:

$$
\left(\frac{\alpha h v}{K}\right)^{1 / 2}=h v-E_{\mathrm{g}}
$$

where $\alpha$ is the absorption coefficient, $K$ is a constant, and $h v$ is the photon energy. $\alpha$ can be obtained using [41]:

$$
\alpha=-\frac{\ln T}{d}
$$

Here, $d$ is the film thickness and $T$ is the transmittance. The insets in Fig. 5 are plotted based on Eq. (2). The $E_{\mathrm{g}}$ value of $300{ }^{\circ} \mathrm{C}$ for $\mathrm{Ta}_{2} \mathrm{O}_{5}$ films on quartz substrate is $4.32 \mathrm{eV}$, while those of $500-900{ }^{\circ} \mathrm{C}$ increase slowly from 4.32 to $4.46 \mathrm{eV}$. The $E_{\mathrm{g}}$ values of $300-900{ }^{\circ} \mathrm{C}$ for $\mathrm{Ta}_{2} \mathrm{O}_{5}$ films on $\mathrm{Si}$ substrate are from 4.46 to $4.51 \mathrm{eV}$. The slight increase in the band gap of $\mathrm{Ta}_{2} \mathrm{O}_{5}$ film on $\mathrm{Si}$ substrate is related to the weak diffusion of $\mathrm{Si}$ into $\mathrm{Ta}_{2} \mathrm{O}_{5}$ film forming $\mathrm{SiO}_{2}$ and/or tantalum silicate $[10,21]$.

Annealing processing also affects the electrochemical properties of $\mathrm{Ta}_{2} \mathrm{O}_{5}$ films. In a typical cyclic voltammetry test, the redox peak current $\left(i_{\mathrm{p}}\right)$ and the scan rate $(v)$ satisfy the following relationship [42]:

$$
i_{\mathrm{p}}=a v^{b}
$$

where $a$ and $b$ are adjustable constants. When $b=0.5$, 
the charge/discharge is controlled by diffusion-controlled electrode process; when $b=1.0$, the charge/discharge is adsorption-controlled electrode process; if $0.5<b<$ 1 , the electrode reaction of $\mathrm{NaCl}$ electrolyte is an irreversible process driven by both adsorption and diffusion [42-44]. Take the logarithm of Eq. (4) at both sides of equal sign, we get the following equation:

$$
\lg i_{\mathrm{p}}=b \lg v+\lg a
$$

Figure 6 plots the cyclic voltammograms (CVs) of 300 and $900{ }^{\circ} \mathrm{C}$ samples dipped into $1 \mathrm{M} \mathrm{NaCl}$ neutral electrolyte collected at potential scan rates from 0.1 to $0.5 \mathrm{~V} / \mathrm{s}$. In Fig. 6(a), redox peaks appearing at $(-0.5)-$ $0.7 \mathrm{~V}$ represent the oxidation/reduction of $\mathrm{Ta}$ ion species on the anode surface. For the scan rate of $0.5 \mathrm{~V} / \mathrm{s}$ anodic peak is broad, about $500 \mathrm{mV}$ and cathodic peak is relatively narrow, about $375 \mathrm{mV}$. The maximum peak currents of anodic and cathodic peaks are 3.0 and $-3.7 \mu \mathrm{A}$, respectively. When the scan rate decreases from 0.4 till $0.1 \mathrm{~V} / \mathrm{s}$, the cathodic peak potentials shift from -0.5 to $0.2 \mathrm{~V}$ in a positive direction (the negative shift of the peak potentials signifies a greater ohmic resistance in the thicker oxide coating) and the peak-to-peak potential separation decreases. While both the anodic/cathodic current peaks decrease in intensity, the cathodic peaks decrease faster. In Fig. 6(b), previous redox peaks are not present. When the scan rate increases from 0.1 to 0.5 $\mathrm{V} / \mathrm{s}$, the peak current gradually increases, and their shapes remain unchanged, reflecting good electrochemical stability of $900{ }^{\circ} \mathrm{C}$ electrode. The maximum peak currents are -0.8 and $0.8 \mu \mathrm{A}$, respectively. This phenomenon occurs probably because the film defects or vacancies are enormously eliminated with $900{ }^{\circ} \mathrm{C}$ annealing, and the capacity of the film surface to capture carriers decreases, leading to performance degradation of the film conductivity and peak current.

The linear relationship between $\log i_{\mathrm{p}}$ and $\log v$ and the slope $b$ values were obtained from the insets of Fig. 6. The $b$ values of $\sim 0.625$ for $300{ }^{\circ} \mathrm{C}$ film and $\sim 0.877$ for $900{ }^{\circ} \mathrm{C}$ film indicate that $\mathrm{Ta}_{2} \mathrm{O}_{5}$ film electrode behaves are driven by both adsorption and diffusion. Further, the $b$ value of $\mathrm{Ta}_{2} \mathrm{O}_{5}$ film electrode increases with annealing temperatures. The possible reason is that annealing reduces the oxygen vacancies, improves the flatness and uniformity of the film, and weakens the ability of the electrode surface to adsorb ions.

Figure 7 shows the XPS results of 300 and $900{ }^{\circ} \mathrm{C}$ electrodes before and after the CV tests and their area ratio graph after $\mathrm{Ta}^{5+} / \mathrm{Ta}^{4+}$ peak position fitting. In Fig. 7 (a), the characteristic peak positions of $\mathrm{Ta}^{5+}$ of $\mathrm{Ta} 4 \mathrm{f}_{7 / 2}$ and $4 \mathrm{f}_{5 / 2}$ of the samples are 26.2 and $28.0 \mathrm{eV}[45,46]$. The presence of surface states or oxygen vacancies may cause partial $\mathrm{Ta}^{5+}$ to lower chemical valence state in the formula of $\mathrm{Ta}_{2} \mathrm{O}_{5-\delta}$ [47]. After fitting the $\mathrm{Ta} 4 \mathrm{f}$ spectral line of (a), a small amount of $\mathrm{Ta}^{4+}$ peaks at 25.7 and $27.9 \mathrm{eV}$ [46] are obtained. In Fig. 7(b), the two pairs of peaks in the sample after the CV test are located at 25.4, 25.9, 27.7, and $27.9 \mathrm{eV}$, respectively. Among them, the 25.9 and $27.9 \mathrm{eV}$ peaks represent $\mathrm{Ta}^{5+}$ in the Ta $4 \mathrm{f}$ spectrum. Further, the $\mathrm{Ta}^{4+}$ content of the sample has increased from $5.27 \%$ to $7.73 \%$ for $4 \mathrm{f}_{7 / 2}$ and from $3.95 \%$ to $5.80 \%$ for $4 \mathrm{f}_{5 / 2}$, which infers that a certain amount of $\mathrm{Ta}^{4+}$ in the $300{ }^{\circ} \mathrm{C}$ sample was produced after the electrochemical test. Thus, the anodic/cathodic peaks in CV test (Fig. 6) may be attributed to the redox transitions of $\mathrm{Ta}^{5+} / \mathrm{Ta}^{4+}[45,48]$. How the specific reactions take place still needs further
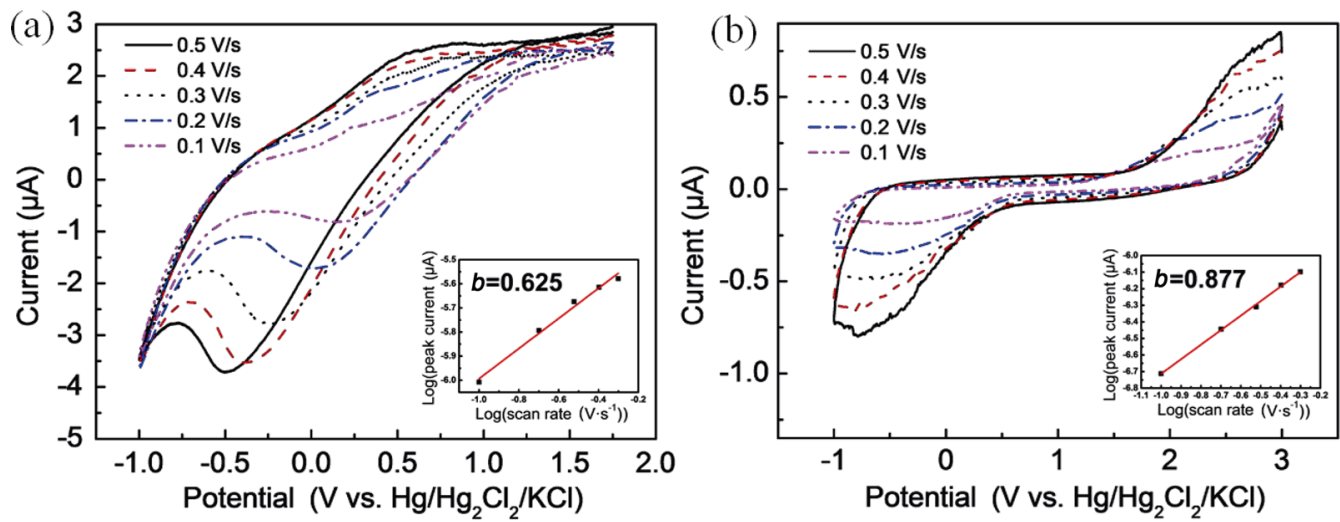

Fig. 6 Cyclic voltammograms of $\mathrm{Ta}_{2} \mathrm{O}_{5} / \mathrm{Si}$ anode electrode at (a) $300{ }^{\circ} \mathrm{C}$ and (b) $900{ }^{\circ} \mathrm{C}$ anneal and their fitting curves in $1 \mathrm{M}$ $\mathrm{NaCl}$ electrolyte at different potential scan rates. The insets: $\log$ (peak current) vs. $\log \left(\mathrm{scan}\right.$ rate) of $\mathrm{Ta}_{2} \mathrm{O}_{5} / \mathrm{Si}_{\text {e electrode at different }}$ annealing temperatures. 

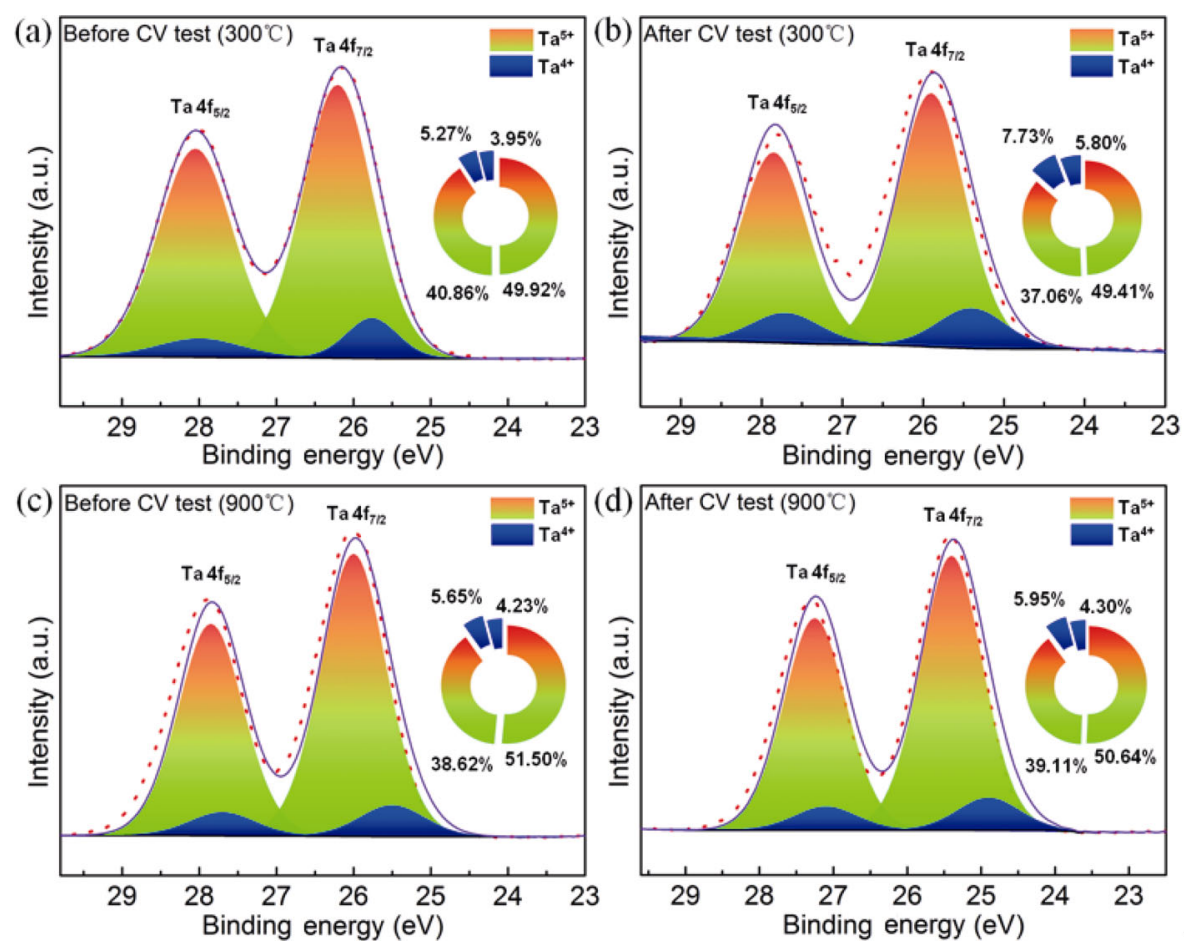

Fig. 7 XPS spectra for $4 \mathrm{f}$ energy levels of $\mathrm{Ta}$ on $\mathrm{Ta}_{2} \mathrm{O}_{5} / \mathrm{Si}$ anode electrodes at 300 and $900{ }^{\circ} \mathrm{C}$ anneal $(\mathrm{a}, \mathrm{c})$ before and (b, d) after the $\mathrm{CV}$ tests, with fitting peaks of $\mathrm{Ta}^{5+} / \mathrm{Ta}^{4+}$ and their contents on film surfaces, respectively.

investigation. With larger reduction peak in Fig. 6(a) than oxidation peak, it might be concluded that the reduction process proceeds faster than the oxidation process and thus, more $\mathrm{Ta}^{4+}$ was generated. In Figs. 7(c) and $7(\mathrm{~d})$, the peak position and content of Ta $4 \mathrm{f}$ do not change much. Due to the symmetrical CV curve of Fig. 6(b), the $\mathrm{Ta}^{5+} / \mathrm{Ta}^{4+}$ redox transition seems to be reversible, which suggests better chemical stability and cyclical performance of the electrode material after $900{ }^{\circ} \mathrm{C}$ heat treatment.

\section{Conclusions}

$\mathrm{Ta}_{2} \mathrm{O}_{5}$ films were synthesized on $\mathrm{Si}(100)$ and quartz substrates via EBE method, followed by annealing at different temperatures in air. Amorphous dense films formed at temperatures between 300 and $700{ }^{\circ} \mathrm{C}$ with enlarged band gap values from 4.32 to $4.46 \mathrm{eV}$. As the annealing temperature increased, the film transmittance was improved due to the higher film density and less defects in the film. Film crystallization of $\beta-\mathrm{Ta}_{2} \mathrm{O}_{5}$ occurred at $900{ }^{\circ} \mathrm{C}$, which produced the highest transmittance rate among these $\mathrm{Ta}_{2} \mathrm{O}_{5}$ films. The smooth and flat film-surface, high film-density, less defects in the film, and crystallization may play vital roles in maintaining the excellent transmittance properties of $\mathrm{Ta}_{2} \mathrm{O}_{5}$ films. The crystallization of amorphous $\mathrm{Ta}_{2} \mathrm{O}_{5}$ film by annealing may lead to the reversible electrochemical reaction inside electrolyte.

\section{Acknowledgements}

This work was supported by the Joint Research Funds of Department of Science \& Technology of Shaanxi Province and Northwestern Polytechnical University (Grant No. 2020GXLH-Z-029).

\section{References}

[1] Qi HJ, Xiao XD, He HB, et al. Optical properties and microstructure of $\mathrm{Ta}_{2} \mathrm{O}_{5}$ biaxial film. Appl Opt 2009, 48: 127-133.

[2] Wang SC, Liu KY, Huang JL. Tantalum oxide film prepared by reactive magnetron sputtering deposition for all-solid-state electrochromic device. Thin Solid Films 2011, 520: 1454-1459.

[3] Chaneliere C, Autran JL, Devine RAB, et al. Tantalum pentoxide $\left(\mathrm{Ta}_{2} \mathrm{O}_{5}\right)$ thin films for advanced dielectric applications. Mater Sci Eng R: Rep 1998, 22: 269-322.

[4] Doumuki T, Tamada H, Saitoh M. Highly efficient Cherenkov-type second harmonic generation in a $\mathrm{Ta}_{2} \mathrm{O}_{5} /$ $\mathrm{KTiOPO}_{4}$ waveguide. Appl Phys Lett 1994, 64: $3533-$ 
3535.

[5] Cid M, Stem N, Brunetti C, et al. Improvements in anti-reflection coatings for high-efficiency silicon solar cells. Surf Coat Technol 1998, 106: 117-120.

[6] Cui Y, Liu SJ, He HB, et al. Influence of vacuum organic contaminations on laser-induced damage of $1064 \mathrm{~nm}$ anti-reflective coatings. Chinese Phys Lett 2007, 24: 2873-2875.

[7] Song YZ, Sakurai T, Maruta $\mathrm{K}$, et al. Optical and structural properties of dense $\mathrm{SiO}_{2}, \mathrm{Ta}_{2} \mathrm{O}_{5}$ and $\mathrm{Nb}_{2} \mathrm{O}_{5}$ thin-films deposited by indirectly reactive sputtering technique. Vacuum 2000, 59: 755-763.

[8] Quah HJ, Ahmad FH, Lim WF, et al. Growth and characterization of ternary $\mathrm{Hf}_{x} \mathrm{Ta}_{y} \mathrm{O}_{z}$ films via nitrogeninfused wet oxidation. ACS Omega 2020, 5: 2634726356.

[9] Sekido Y. Characteristics of $\mathrm{Ta}_{2} \mathrm{O}_{5}$ thin film prepared by electron beam heating method. Electron Commun Jpn Part II: Electron 1994, 77: 54-61.

[10] Xu C, Yang S, Wang JF, et al. Effect of oxygen vacancy on the band gap and nanosecond laser-induced damage threshold of $\mathrm{Ta}_{2} \mathrm{O}_{5}$ films. Chinese Phys Lett 2012, 29: 084207.

[11] $\mathrm{Xu} \mathrm{C}$, Dong $\mathrm{HC}, \mathrm{Ma} J \mathrm{Y}$, et al. Influences of $\mathrm{SiO}_{2}$ protective layers and annealing on the laser-induced damage threshold of $\mathrm{Ta}_{2} \mathrm{O}_{5}$ films. Chin Opt Lett 2008, 6: 228-230.

[12] Cheng WH, Chi SF, Chu AK. Effect of thermal stresses on temperature dependence of refractive index for $\mathrm{Ta}_{2} \mathrm{O}_{5}$ dielectric films. Thin Solid Films 1999, 347: 233-237.

[13] Ezhilvalavan S, Tseng TY. Preparation and properties of tantalum pentoxide $\left(\mathrm{Ta}_{2} \mathrm{O}_{5}\right)$ thin films for ultra large scale integrated circuits (ULSIs) application - A review. J Mater Sci: Mater Electron 1999, 10: 9-31.

[14] Atanassova E, Paskaleva A. Challenges of $\mathrm{Ta}_{2} \mathrm{O}_{5}$ as high-k dielectric for nanoscale DRAMs. Microelectron Reliab 2007, 47: 913-923.

[15] Zhou MF, Fu ZW, Yang HJ, et al. Pulsed laser deposition of tantalum oxide thin films. Appl Surf Sci 1997, 108: 399-403.

[16] Xia SL, Ni JF, Savilov SV, et al. Oxygen-deficient $\mathrm{Ta}_{2} \mathrm{O}_{5}$ nanoporous films as self-supported electrodes for lithium microbatteries. Nano Energy 2018, 45: 407-412.

[17] Hudner J, Hellberg PE, Kusche D, et al. Tantalum oxide films on silicon grown by tantalum evaporation in atomic oxygen. Thin Solid Films 1996, 281-282: 415-418.

[18] Mannequin C, Tsuruoka T, Hasegawa $\mathrm{T}$, et al. Identification and roles of nonstoichiometric oxygen in amorphous $\mathrm{Ta}_{2} \mathrm{O}_{5}$ thin films deposited by electron beam and sputtering processes. Appl Surf Sci 2016, 385: 426-435.

[19] Devine RAB, Chaneliere C, Autran JL, et al. Use of carbon-free $\mathrm{Ta}_{2} \mathrm{O}_{5}$ thin-films as a gate insulator. Microelectron Eng 1997, 36: 61-64.

[20] Lukosius M, Kaynak CB, Kubotsch S, et al. Properties of atomic-vapor and atomic-layer deposited $\mathrm{Sr}, \mathrm{Ti}$, and $\mathrm{Nb}$ doped $\mathrm{Ta}_{2} \mathrm{O}_{5}$ Metal-Insulator-Metal capacitors. Thin Solid Films 2012, 520: 4576-4579.

[21] Krishnan RR, Nissamudeen KM, Gopchandran KG, et al. Effect of doping and substrate temperature on the structural and optical properties of reactive pulsed laser ablated tin oxide doped tantalum oxide thin films. Vacuum 2010, 84: 1204-1211.

[22] Byeon SG, Tzeng Y. High performance sputtered/anodized tantalum oxide capacitors. In: Proceedings of the International Electron Devices Meeting, 1988: 722-725.

[23] Reddy PK, Jawalekar SR. Improved properties of $\mathrm{TaNTa}_{2} \mathrm{O}_{5} \mathrm{~N}_{x} \mathrm{Al}$ capacitors. Thin Solid Films 1979, 64: 71-76.

[24] Ozer N, Lampert CM. Structural and optical properties of sol-gel deposited proton conducting $\mathrm{Ta}_{2} \mathrm{O}_{5}$ films. $J$ Sol-Gel Sci Technol 1997, 8: 703-709.

[25] Zhang DX, Zheng YX, Cai QY, et al. Thicknessdependence of optical constants for $\mathrm{Ta}_{2} \mathrm{O}_{5}$ ultrathin films. Appl Phys A 2012, 108: 975-979.

[26] Masse JP, Szymanowski H, Zabeida O, et al. Stability and effect of annealing on the optical properties of plasma-deposited $\mathrm{Ta}_{2} \mathrm{O}_{5}$ and $\mathrm{Nb}_{2} \mathrm{O}_{5}$ films. Thin Solid Films 2006, 515: 1674-1682.

[27] $\mathrm{He} X, \mathrm{Wu}$ J, Li X, et al. Characterization of high quality tantalum pentoxide film synthesized by oxygen plasma enhanced pulsed laser deposition. Thin Solid Films 2009, 518: 94-98.

[28] Liu WJ, Chien CH. Influences of residual argon gas and thermal annealing on $\mathrm{Ta}_{2} \mathrm{O}_{5}$ thin films. Jpn J Appl Phys 2005, 44: 181-186.

[29] Ghodsi FE, Tepehan FZ, Tepehan GG. Optical properties of $\mathrm{Ta}_{2} \mathrm{O}_{5}$ thin films deposited using the spin coating process. Thin Solid Films 1997, 295: 11-15.

[30] Huang AP, Chu PK. Crystallization improvement of $\mathrm{Ta}_{2} \mathrm{O}_{5}$ thin films by the addition of water vapor. J Cryst Growth 2005, 274: 73-77.

[31] Chandra SVJ, Uthanna S, Rao GM. Effect of substrate temperature on the structural, optical and electrical properties of dc magnetron sputtered tantalum oxide films. Appl Surf Sci 2008, 254: 1953-1960.

[32] Dimitrova T, Arshak K, Atanassova E. Crystallization effects in oxygen annealed $\mathrm{Ta}_{2} \mathrm{O}_{5}$ thin films on Si. Thin Solid Films 2001, 381: 31-38.

[33] Xu C, Dong HC, Yuan L, et al. Investigation of annealing effects on the laser-induced damage threshold of amorphous $\mathrm{Ta}_{2} \mathrm{O}_{5}$ films. Opt Laser Technol 2009, 41: 258-263.

[34] Porqueras I, Marti J, Bertran E. Optical and electrical characterisation of $\mathrm{Ta}_{2} \mathrm{O}_{5}$ thin films for ionic conduction applications. Thin Solid Films 1999, 343-344: 449-452.

[35] Xu C, Yao JK, Ma JY, et al. Laser-induced damage threshold in n-on-1 regime of $\mathrm{Ta}_{2} \mathrm{O}_{5}$ films at 532, 800, and 1064 nm. Chin Opt Lett 2007, 5: 727-729.

[36] Xu C, Xiao QL, Ma JY, et al. High temperature annealing effect on structure, optical property and laser-induced damage threshold of $\mathrm{Ta}_{2} \mathrm{O}_{5}$ films. Appl Surf Sci 2008, 254: 
6554-6559.

[37] Gladczuk L, Patel A, Singh Paur C, et al. Tantalum films for protective coatings of steel. Thin Solid Films 2004, 467: $150-157$.

[38] Zhou JC, Luo DT, Li YZ, et al. Properties of $\mathrm{Ta}_{2} \mathrm{O}_{5}$ thin films deposited by dc reactive magnetron sputtering. Int $J$ Mod Phys B 2009, 23: 5275-5282.

[39] Li XH, Ji T, Hu J, et al. Optimization of specimen preparation of thin cell section for AFM observation. Ultramicroscopy 2008, 108: 826-831.

[40] Tauc J. Amorphous and Liquid Semiconductors. Boston: Springer US, 1974.

[41] Meng LJ, dos Santos MP. Investigations of titanium oxide films deposited by d.c. reactive magnetron sputtering in different sputtering pressures. Thin Solid Films 1993, 226: 22-29.

[42] Augustyn V, Come J, Lowe MA, et al. High-rate electrochemical energy storage through $\mathrm{Li}^{+}$intercalation pseudocapacitance. Nat Mater 2013, 12: 518-522.

[43] Xie ZK, Wu YM, Kai S, et al. A newly competitive electrochemical sensor for sensitive determination of chrysin based on electrochemically activated $\mathrm{Ta}_{2} \mathrm{O}_{5}$ particles modified carbon paste electrode. Electroanalysis 2017, 29: 835-842.

[44] Xie ZK, Li GP, Fu YM, et al. Sensitive, simultaneous determination of chrysin and baicalein based on $\mathrm{Ta}_{2} \mathrm{O}_{5}$-chitosan composite modified carbon paste electrode. Talanta 2017, 165: 553-562.
[45] NuLi YN, Fu ZW, Chu YQ, et al. Electrochemical and electrochromic characteristics of $\mathrm{Ta}_{2} \mathrm{O}_{5}-\mathrm{ZnO}$ composite films. Solid State Ionics 2003, 160: 197-207.

[46] Simpson R, White RG, Watts JF, et al. XPS investigation of monatomic and cluster argon ion sputtering of tantalum pentoxide. Appl Surf Sci 2017, 405: 79-87.

[47] Wu T, Jin, Xiao W, et al. Thin pellets: Fast electrochemical preparation of capacitor tantalum powders. Chem Mater 2007, 19: 153-160.

[48] Wen TC, Hu CC. Hydrogen and oxygen evolutions on Ru-Ir binary oxides. J Electrochem Soc 1992, 139: 2158 2163.

Open Access This article is licensed under a Creative Commons Attribution 4.0 International License, which permits use, sharing, adaptation, distribution and reproduction in any medium or format, as long as you give appropriate credit to the original author(s) and the source, provide a link to the Creative Commons licence, and indicate if changes were made.

The images or other third party material in this article are included in the article's Creative Commons licence, unless indicated otherwise in a credit line to the material. If material is not included in the article's Creative Commons licence and your intended use is not permitted by statutory regulation or exceeds the permitted use, you will need to obtain permission directly from the copyright holder.

To view a copy of this licence, visit http://creativecommons. org/licenses/by/4.0/. 